\title{
PENERAPAN IOT (INTERNET OF THINGS) PADA PEMANTAUAN KESEHATAN KANDANG HEWAN JENIS LANDAK MINI BERBASIS ARDUINO DENGAN MENGGUNAKAN METODE LOGIKA FUZZY
}

\author{
Mohammad Rizal Muzaky, Yosep Agus Pranoto, Nurlaily Vendyansyah \\ Program Studi Teknik Informatika S1, Fakultas Teknologi Industri \\ Institut Teknologi Nasional Malang, Jalan Raya Karanglo km 2 Malang, Indonesia \\ rizalmuzaky108@gmail.com
}

\begin{abstract}
ABSTRAK
Hobi merawat binatang bagi sebagian orang dari usia muda sampai orang dewasa memiliki minat tersendiri, salah satunya memelihara binatang berjenis landak mini atau mempunyai bahasa latin hedgehog yang termasuk kedalam keluarga erinaceinae. Mengontrol suhu dan kelembaban kandang landak mini sangat penting bagi para pemelihara hewan tersebut apalagi ketika pemilik sedang tidak dirumah, landak mini dapat dipelihara dalam kotak kayu atau aquarium akrilik sebagai tempat pemeliharaan sehingga tidak memakan tempat yang lebih besar. Dengan permasalahan latar belakang tersebut, penelitian mengembangkan sistem monitoring hewan jenis landak mini berbasis internet of things(IOT) agar pemilik dapat melakukan pemantauan kandang saat sedang tidak dirumah dan memberikan informasi secara langsung melalui internet, pada sistem ini terdapat beberapa sensor, modul dan aktuator ke dalam pembuatan sistem monitoring kandang hewan jenis landak mini berbasis Arduino seperti sensor DHT11, Motor Servo, sensor WaterLevel dan sensor Load Cell, Waterpump, Motor servo, lcd Display i2c,Hx711, L298N, Kipas dan Esp8266 yang digunakan untuk memonitoring kandang, sensor DHT11 digunakan untuk mendeteksi suhu dan kelembaban pada kandang, sensor Water Level digunakan untuk mendeteksi air minum pada kandang. Dari hasil perhitungan, diketahui pengujian alat menggunakan sensor dht1 1 memiliki nilai keakuratan sebesar $\pm 93.82 \%$ dengan rata presentase error sebesar $6,28 \%$, sensor load cell memiliki nilai rata presentase error sebesar 3,08\% sedangkan tingkat error pada sensor waterlevel sebesar $0,18 \%$, kipas dapat menyala dengan kecepatan yang telah dihasilkan menggunakan basis aturan fuzzy mamdani, ketika suhu dan kelembaban kandang mencapai kondisi keanggotaan dingin, dan normal maka kipas akan berputar sedang, jika suhu dan kelembaban kandang mencapai panas dan lembab maka kipas akan menyala dengan cepat.
\end{abstract}

Kata Kunci: Landak Mini, Logika Fuzzy, Mamdani, Suhu, Kelembaban, Php, MySQL

\section{PENDAHULUAN}

Hobi merawat binatang bagi sebagian orang dari usia muda sampai orang dewasa memiliki minat tersendiri, salah satunya memelihara binatang berjenis landak mini atau mempunyai bahasa latin hedgehog yang termasuk kedalam keluarga erinaceinae. Mengontrol suhu dan kelembaban kandang landak mini sangat penting bagi para pemelihara hewan tersebut, landak mini dapat dipelihara dalam kotak kayu atau aquarium akrilik sebagai tempat pemeliharaan sehingga tidak memakan tempat yang lebih besar.

Pemantauan kesehatan kandang jenis hewan landak mini pada umumnya memang memerlukan sedikit perhatian dikarenakan hewan kecil ini akan mudah sakit apabila salah dalam cara merawatnya dengan baik. Banyak kendala yang dihadapi pemilik salah satunya tidak memberi pakan secara teratur dan juga menjaga suhu dan kelembaban kandang tetap normal. Permasalahan tersebut banyak dijumpai pada kandang konvensional pada umumnya, oleh karena itu diperlukan sistem yang dapat menjaga landak mini tetap sehat sesuai dengan perkembangan teknologi sekarang.

Dengan itulah peneliti mengembangkan sistem monitoring hewan jenis landak mini berbasis internet of things(IOT) agar memberikan informasi secara langsung melalui internet, pada sistem ini terdapat beberapa sensor, modul dan aktuator ke dalam pembuatan sistem monitoring kandang hewan jenis landak mini berbasis Arduino seperti sensor DHT11, Motor Servo, sensor WaterLevel dan sensor Load Cell, Waterpump, Motor servo, lcd Display i2c,Hx711, L298N, Kipas dan Esp8266 yang digunakan untuk memonitoring kandang, sensor DHT11 digunakan untuk mendeteksi suhu dan kelembaban pada kandang, sensor Water Level digunakan untuk mendeteksi air minum pada kandang, Motor servo sebagai pemberi pakan otomatis ke dalam kandang.

Berdasarkan penelitian sebelumnya berjudul "Implementasi Fuzzy Logic Mamdani Untuk pengendalian Suhu dan Kelembaban Pada Terrarium Reptil dan Monitoring berbasis IOT" dimana pengontrolan sistem masih menggunakan sistem lama yaitu aplikasi android yang dimana memerlukan berbagai instalasi sehingga menjadi kurang efektif, dari kekurangan tersebut peneliti mencoba meneruskan dan merancang sistem dengan menggunakan website sebagai alat monitoring. Penggunaan logika fuzzy mamdani lebih efektif dan 
stabil dapat memantau tingkat suhu dan kelembaban pada kandang.

\section{TINJAUAN PUSTAKA}

\subsection{Penelitian Terdahulu}

Penelitian tentang logika fuzzy telah dilakukan oleh beberapa peneliti dan menuliskan hasilnya dalam bentuk jurnal berjudul, "Rancang Bangun Pengontrol Suhu Ruangan Berbasis Mikrokontroller Arduino Uno" Tujuan penelitian tersebut adalah memudahkan pengguna dalam mengontrol suhu dan kelembaban ruangan untuk tetap berada dalam kondisi nyaman. Adapun persamaan dari penelitian ini menggunakan sistem untuk mengetahui tingkat suhu pada ruangan dan yang menjadi perbedaan dengan sistem yang dibuat peneliti adalah sistem yang dibuat peneliti menggunakan sensor berbeda untuk melakukan kegiatan pengecekan suhu sehingga output data akan berbeda dilihat dari besar nya ruangan (Yolnasdi, Arviansyah, Dedy Irfan, \& Ambiyar, 2020).

Selanjutnya, "Implementasi Fuzzy Logic Mamdani Untuk Pengendalian Suhu dan Kelembaban Pada Terrarium Reptil dan Monitoring Berbasis IOT". Tujuan penelitian ini yaitu untuk membuat sistem pengatur suhu dan kelembaban pada sebuah kandang reptil atau biasa disebut terrarium dengan menggunakan metode fuzzy logic mamdani pada sistem Arduino. Adapun persamaan dari penelitian ini tentu sama-sama mengukur tingkat suhu dan kelembaban pada suatu kandang hewan dan perbedaan dengan sistem yang dibuat penulis yaitu perbedaan sensor dan metode fuzzy (Fathkhur Rohman, Julian Sahertian, \& Ardi Sanjaya, 2020).

Lalu, "Implementasi Logika Fuzzy pada Sistem Monitoring Online Suhu Sapi Potong berbasis IOT" Tujuan penelitian tersebut adalah untuk menentukan lama tidaknya mini water pump menyala, Dengan adanya sistem ini pengelola ternak diharapkan dapat memantau suhu lingkungan dan suhu sapi, sehingga dapat menjaga suhu sapi tetap stabil. Adapun persamaan dari penelitian ini menggunakan monitoring dan yang menjadi perbedaan dengan sistem yang dibuat $\mathrm{Abi}$, adalah sistem yang dibuat penulis menggunakan sensor berbeda untuk melakukan kegiatan monitoring (Abi Tresna, 2021).

Sedangkan, "Rancang Bangun Control Suhu dan Kelembaban pada Kumbung Jamur berbasis Logika Fuzzy" Tujuan Penelitian tersebut adalah diharapkan dapat bermanfaat untuk petani dalam mengendalikan temperatur dan kelembaban secara optimal guna meningkatkan produktivitas jamur tiram sehingga pendapatan petani jamur dapat meningkat sehingga jamur tiram dapat dibudidayakan sepanjang tahun tanpa terkendali kondisi lingkungan yang berarti. Perancangan alat ini terdiri dari dua bagian, yaitu perancangan dan pembuatan perangkat keras sehingga pembuatan perangkat lunak. Perancangan alat ini dilakukan bertahap untuk mempermudah dalam hal menganalisis data. Pada pengujian kumbung dengan kontrol Fuzzy, dilakukan perbandingan dengan mencari data pembanding dari alat yang sama dengan kontrol yang berbeda untuk mencari nilai persentase error alat. Nilai persentase error alat kumbung dengan kontrol Fuzzy. Adapun persamaan dari penelitian ini tentu sama-sama menggunakan sistem monitoring dan yang menjadi perbedaan dengan sistem yang dibuat Eka, adalah sistem yang dibuat penulis menggunakan sensor berbeda untuk melakukan kegiatan monitoring (Eka Pratama Saksono, 2019).

Selanjutnya, "Sistem Pemberi Pakan Otomatis, $\mathrm{Ph}$ Regulator dan Kendali Suhu Menggunakan Fuzzy Logic Pada Aquarium" Tujuan penelitian tersebut adalah memberikan solusi untuk para penghobi akuarium ikan hias atau aquascape dengan membangun suatu akuarium pintar atau smart aquarium. Adapun persamaan dari penelitian ini adalah bagaimana cara membuat sebuah sistem yang dapat memberikan dampak positif terhadap para pemilik hewan apabila tidak mempunyai waktu karena kesibukan atau pekerjaan dan perbedaan dari penelitian adalah beberapa sensor yang digunakan dan juga objek terkait (Allya Allan Putra Syah, Ketty Siti Salamah, \& Eko Ihsanto, 2019).

\subsection{Logika Fuzzy}

Logika Fuzzy adalah tingkatan dari logika Boolean yang berhadapan dengan konsep kebenaran sebagian. Saat logika klasik menyatakan bahwa segala hal dapat diekspresikan dalam istilah biner (0 atau 1 , hitam atau putih, ya atau tidak), logika fuzzy menggantikan kebenaran boolean dengan tingkat kebenaran. Logika Fuzzy memungkinkan nilai keanggotaan antara 0 dan 1, tingkat keabuan dan juga hitam dan putih, dan dalam bentuk linguistik, konsep tidak pasti seperti "sedikit", "lumayan", dan "sangat".

\subsection{Mamdani}

Metode Fuzzy Mamdani merupakan salah satu bagian dari Fuzzy Inference System yang berguna untuk penarikan kesimpulan atau suatu keputusan terbaik dalam permasalahan yang tidak pasti. Metode Fuzzy Mamdani diperkenalkan oleh Ebrahim Mamdani pada tahun 1975. Metode Fuzzy Mamdani dalam prosesnya menggunakan kaedah-kaedah linguistik dan memiliki algoritma fuzzy yang dapat dianalisis secara matematika, sehingga lebih mudah dipahami (Febriany, 2016).

\subsection{IoT (Internet of Things)}

Internet of things adalah suatu konsep atau program dimana sebuah objek memiliki kemampuan untuk mentransmisikan atau mengirimkan data melalui jaringan tanpa menggunakan bantuan perangkat komputer dan manusia. Penggunaan IoT dapat diimplementasikan pada berbagai hal salah satunya adalah perkuliahan, pribadi, dan sebagainya yang dapat diakses dari mana saja. 


\subsection{Sensor DHT11}

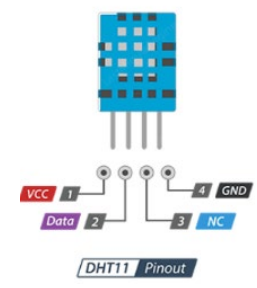

Gambar 1. Sensor DHT11

Sensor DHT merupakan paket sensor yang berfungsi untuk mengukur suhu, sebuah sensor kelembaban dengan karakteristik resistif terhadap perubahan kadar air di udara serta terdapat chip yang di dalamnya melakukan beberapa konversi analog ke digital dan mengeluarkan output dengan format tunggal dua arah.

DHT memiliki 2 tipe sensor, perbedaan keduanya diketahui DHT11 dan DHT22 sama, untuk input tegangan memiliki range tegangan $3 \mathrm{~V}-5 \mathrm{~V}$ serta konsumsi arus maksimal $2.5 \mathrm{~mA}$ saat meminta data. Perbedaan terletak pada range DHT22 lebih luas daripada DHT11 untuk pembacaan kelembaban 0100 dengan akurasi lebih akurat 2-5\% serta pembacaan suhu -40 hingga $80^{\circ} \mathrm{C}$ dengan akurasi \pm $0,5^{\circ} \mathrm{C}$.

\subsection{Sensor Water level}

$$
=\sqrt{a g}
$$

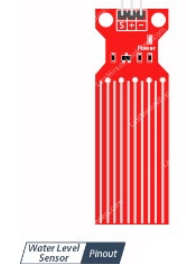

Gambar 2. Sensor Water level

Water Level Sensor adalah alat yang digunakan untuk memberikan signal kepada alarm / automation panel bahwa permukaan air telah mencapai level tertentu. Sensor akan memberikan signal dry contact (NO/NC) ke panel. Water sensor ini telah dilengkapi dengan built-in buzzer yang berbunyi pada saat terjadi tingkat air yang terkena panel.

\subsection{Sensor Load Cell}

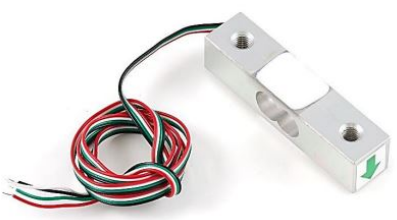

Gambar 3. Sensor Load Cell

Load Cell adalah alat electromekanik yang biasa disebut Transducer, yaitu gaya yang bekerja berdasarkan prinsip deformasi sebuah material akibat adanya tegangan mekanis yang bekerja, kemudian merubah gaya mekanik menjadi sinyal listrik. Untuk menentukan tegangan mekanis didasarkan pada hubungan antara tegangan mekanis dan deformasi yang diakibatkan disebut regangan. Regangan ini terjadi pada lapisan kulit dari material sehingga menungkinkan untuk diukur menggaunakan sensor regangan atau Strain Gauge.

\subsection{Motor Servo}

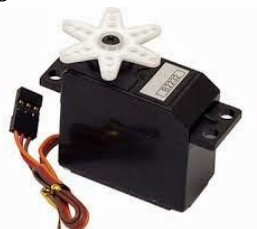

Gambar 4. Motor Servo

Motor servo standard (servo rotation $180^{\circ}$ ) adalah jenis yang paling umum dari motor servo, dimana putaran poros outputnya terbatas hanya $90^{\circ}$ kearah kanan dan $90^{\circ}$ kearah kiri. Dengan kata lain total putarannya hanya setengah lingkaran atau $180^{\circ}$.

\subsection{RTC DS3231}

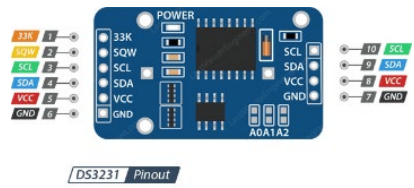

Gambar 5. RTC DS3231

Modul RTC merupakan sistem pengingat waktu dan tanggal yang menggunkan baterai sebagai cadangan tenaga agar modul ini tetap berjalan. Modul ini memperbarui tanggal dan waktu secara berkala, sehingga kita dapat menerima tanggal dan waktu yang akurat dari kapanpun kita membutuhkan.

\subsection{Motor Driver}

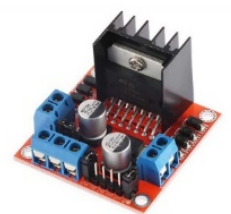

Gambar 6. Motor Driver L298N

Driver motor L298N merupakan modul driver motor DC yang paling banyak digunakan atau dipakai di dunia elektronika yang difungsikan untuk mengontrol kecepatan sehingga arah perputaran motor DC dapat dikendalikan. 


\subsection{LCD Display i2c}

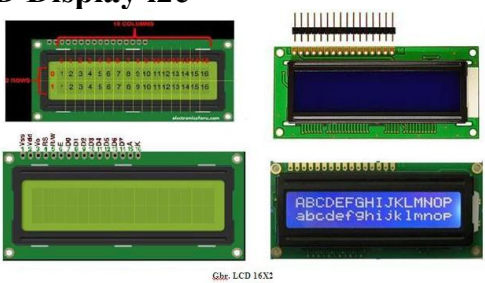

Gambar 7. LCD 20x4 i2c

LCD (Liquid Crystal Display) adalah jenis media tampilan atau Display dari bahan cairan kristal sebagai penampil utama. LCD dapat menampilkan sebanyak 80 karakter yang terdiri dari 4 baris dengan tiap baris menampilkan 20 karakter.

\section{METODE PENELITIAN}

\subsection{Analisa Kebutuhan Fungsional}

a. Sistem dapat mendeteksi sisa pakan dan minum secara otomatis

b. Sistem dapat memonitoring pakan, tingkat suhu, kelembaban dan sisa air minum dalam kandang

\subsection{Diagram Blok Sistem Monitoring Kandang} Hewan Jenis landak mini

Sistem Monitoring ini menggunakan Arduino sebagai data masukan berupa sensor DHT11, sensor Water Level, sensor Load Cell, kemudian RTC memberikan inputan data ke NodeMCU ESP8266. Selanjutnya, data dikirim ke LCD dan motor servo sehingga katub pada wadah pakan utama akan terbuka. Tampilan Web sebagai sistem monitoring data pakan, suhu, kelembaban dan ketersediaan air minum pada kandang, data yang di dapatkan dari sensor akan disimpan dalam database. Blok diagram sistem monitoring hewan jenis landak mini dapat dilihat pada Gambar 8

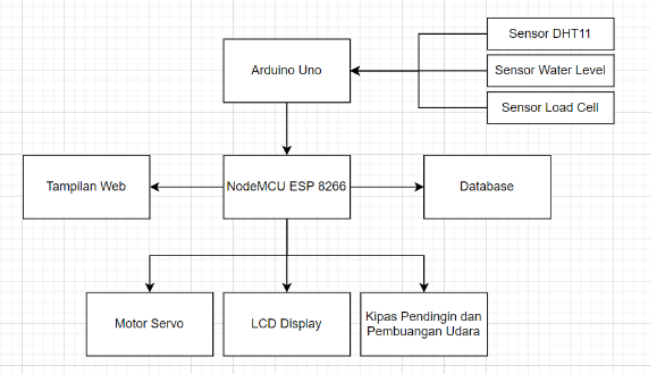

Gambar 8. Diagram blok sistem monitoring kandang hewan jenis landak mini

\subsection{Flowchart Sistem}

Flowchart sistem ini menjelaskan alur berjalannya sistem seperti yang ditunjukkan pada Gambar 9

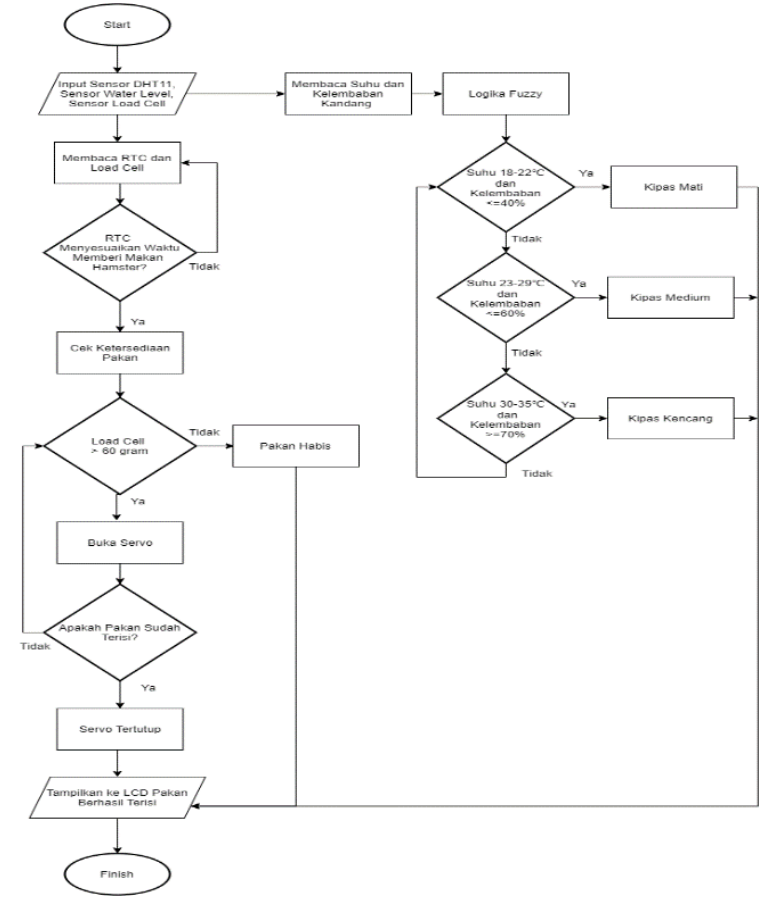

Gambar 9. Tampilan Flowchart Alur Sistem

Pertama akan melakukan pengecekan sisa pakan dengan menyesuaikan waktu pemberian pakan. Kemudian inisialisasi range pakan dengan sensor Load Cell, servo akan terbuka untuk proses pemberian pakan jika pakan dibawah batas normal dan servo akan tertutup jika pakan sudah terisi, status pakan akan ditampilkan ke dalam LCD. Pada kasus ini, inisialisasi range yang ditentukan untuk sensor suhu dan kelembaban adalah $18-35^{\circ} \mathrm{C}$ dan $40-$ $70 \%$ RH. Kemudian data sensor yang didapatkan akan dikirim ke dalam database dan ditampilkan dengan visual website yang terintegrasi.

\subsection{Flowchart Metode Logika Fuzzy Mamdani}

Adapun Metode yang akan digunakan pada pengerjaan program ini dapat dilihat pada Gambar 10

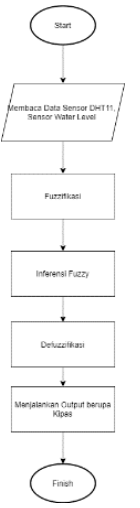

Gambar 10. Tampilan Flowchart Logika Fuzzy

Pada Gambar 10 diatas, Tahap-tahap proses tersebut meliputi fuzzifikasi, inferensi fuzzy dan defuzzifikasi. Dalam metode Fuzzy menunjukkan bahwa proses pada control Fuzzy memiliki fungsi yang saling terhubung dengan proses lain sehingga 
dapat dihasilkan input dari proses sebelumnya sampai outputan akhir sistem. hasil data dari sensor-sensor tersebut akan dijadikan data input sistem. Data masukan akan diproses menggunakan metode logika fuzzy.

\subsection{Struktur Alat}

Struktur menu yang akan dirancang di dalam sistem ini dapat dilihat pada Gambar 11

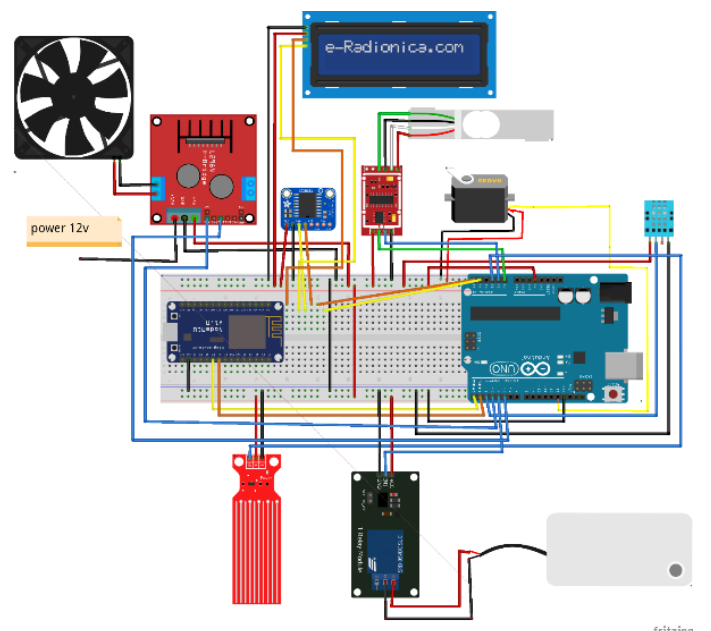

Gambar 11. Tampilan Struktur Menu

Pada gambar diatas, Sistem monitoring kandang hewan jenis landak mini Pada tahapan implementasi perangkat keras ini, dilakukan perakitan terhadap komponen-komponen dengan menggunakan media fritzing.

\section{HASIL DAN PEMBAHASAN}

\subsection{IMPLEMENTASI SISTEM}

1. Tampilan Halaman Login

Pada halaman ini, user harus login terlebih dahulu agar dapat mengakses sistem monitoring seperti Gambar 12 dibawah ini.

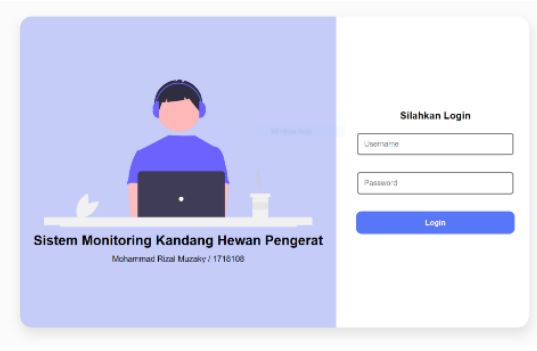

Gambar 12. Tampilan Halaman Login

\section{Halaman Nilai Sensor}

Pada halaman ini, nilai tabel sensor yang ditampilkan adalah nilai yang dikirimkan dari nodeMCU seperti pada Gambar 13

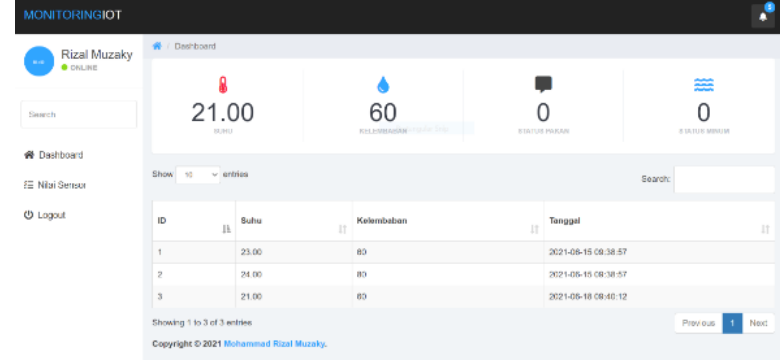

Gambar 13. Tampilan Halaman Nilai Sensor

\subsection{Himpunan Keanggotaan Fuzzy}

Himpunan keanggotaan fuzzy yang akan digunakan dalam sistem menggunakan perhitungan logika fuzzy adalah sebagai berikut:

a. Himpunan keanggotaan suhu

Dimana himpunan keanggotaan suhu adalah keanggotaan dingin memiliki range antara 15 sampai dengan 25, untuk keanggotaan normal memiliki range antara 23 sampai dengan 32, untuk keanggotaan panas memiliki range antara 30 sampai dengan 40 .

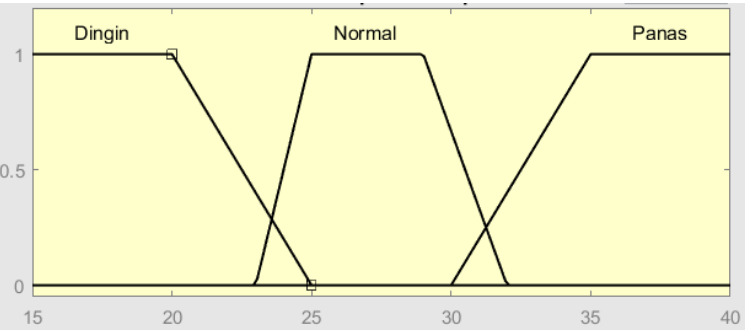

Gambar 14. Himpunan Keanggotaan Suhu

Jika dimasukkan kedalam rumus keanggotaan, maka sebagai berikut:

$$
\begin{aligned}
& \text {-Dingin } \\
& 1 \quad, x \leq 20 \\
& \frac{25-x}{25-20} \quad, 20 \leq x \leq 25 \\
& \text { o }{ }_{a} x \leq 23 \\
& \frac{x-23}{25-23} \quad, 23 \leq x \leq 25 \\
& 0 \quad, \geq 25 \\
& 1 \quad, 25 \leq x \leq 29 \\
& \frac{32-x}{32-29} \quad, 32 \geq x \geq 29
\end{aligned}
$$

-Panas

$$
\begin{array}{ll}
\frac{0}{x-30} & x \leq 30 \\
\frac{x 5-30}{35} & , 30 \leq x \leq 35 \\
1 & \geq 35
\end{array}
$$

b. Himpunan Keanggotaan Kelembaban

Himpunan keanggotaan kelembaban adalah dingin memiliki range antara 0 sampai dengan 40, untuk keanggotaan normal memiliki range antara 30 sampai dengan 70, untuk keanggotaan panas memiliki range antara 60 sampai dengan 100 . 


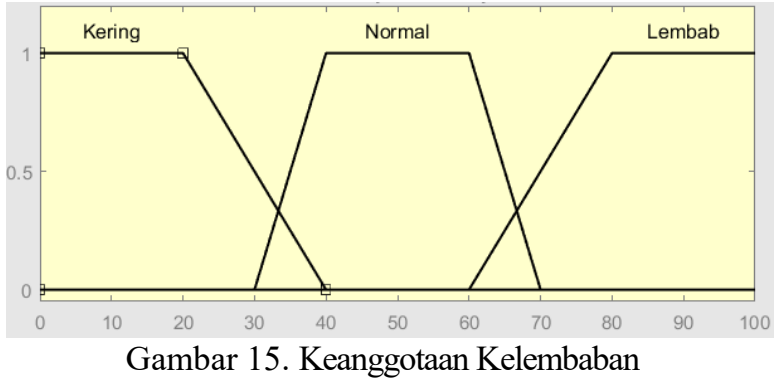

Jika dimasukkan kedalam rumus keanggotaan, maka sebagai berikut:

$$
\begin{aligned}
& \text {-Kering } \\
& \begin{array}{clcl}
1 & , x \leq 20 & 0 & , x \leq 30 \\
\frac{40-x}{40-20} & , 20 \leq x \leq 40 & \frac{x-30}{40-30} & , 30 \leq x \leq 40 \\
0 & , \geq 40 & 1 & , 40 \leq x \leq 60 \\
& & \frac{70-x}{70-60} & , 70 \geq x \geq 60
\end{array} \\
& \text {-Lembab } \\
& \begin{array}{ll}
\frac{x-60}{80-60}, & x \leq 60 \leq x \leq 80 \\
1 & \geq 80
\end{array}
\end{aligned}
$$

\subsection{Rule Base Fuzzy dan Defuzzifikasi}

Nilai keanggotaan fuzzy, kemudian nilai akan masuk ke dalam basis aturan.

a. Rule Base Suhu dan Kelembaban

Rule keanggotaan suhu dan kelembaban memiliki masing masing 3 kondisi yaitu untuk suhu terdapat dingin, normal, panas dan kelembaban terdapat kering, normal, lembab. Rule base suhu dan kelembaban dapat dilihat pada tabel 1 .

Tabel 1. Rule Base Suhu dan Kelembaban

\begin{tabular}{|l|c|c|c|}
\hline No. & Suhu & Kelembaban & Kondisi Kipas \\
\hline 1. & Dingin & Kering & Mati \\
\hline 2. & Dingin & Normal & Mati \\
\hline 3. & Dingin & Lembab & Nyala Pelan \\
\hline 4. & Normal & Kering & Nyala Pelan \\
\hline 5. & Normal & Normal & Nyala Pelan \\
\hline 6. & Normal & Lembab & Nyala Sedang \\
\hline 7. & Panas & Kering & Nyala Sedang \\
\hline 8. & Panas & Normal & Nyala Sedang \\
\hline 9. & Panas & Lembab & Nyala Lama \\
\hline
\end{tabular}

\subsection{PENGUJIAN SISTEM}

1. Pengujian sistem monitoring kandang hewan jenis landak mini

Pada Pengujian ini, dilakukan pengujian fitur-fitur yang ada pada sistem monitoring, nilai sensor dari Arduino akan dikirimkan ke dalam database dan ditampilkan ke dalam web monitoring. Hasil pengujian fungsional sistem ditunjukan dalam Tabel 2.

Tabel 2.Tabel Pengujian load cell dan motor servo

\begin{tabular}{|c|c|c|}
\hline No. & Load cell (gram) & Kondisi Servo \\
\hline 1. & 50 & Mati \\
\hline 2. & 10 & Terbuka \\
\hline
\end{tabular}

\begin{tabular}{|c|c|c|}
\hline 3. & 18 & Terbuka \\
\hline 4. & 30 & Mati \\
\hline 5. & 25 & Mati \\
\hline
\end{tabular}

Dengan hasil pungujian sensor pada tabel 2, didapatkan hasil sensor load cell membaca berat

\begin{tabular}{|c|c|c|c|c|c|}
\hline \multirow{2}{*}{ No. } & \multirow{2}{*}{$\begin{array}{c}\text { Data Set Sensor } \\
\text { Water Level }\end{array}$} & \multicolumn{2}{|c|}{ Pompa } & \multirow{2}{*}{$\begin{array}{l}\text { Lama } \\
\text { Menyala }\end{array}$} & \multirow{2}{*}{$\begin{array}{l}\text { Kondisi } \\
\text { Pompa }\end{array}$} \\
\hline & & Nyala & Mati & & \\
\hline 1. & Kondisi Kosong ke 1 & $\checkmark$ & $\mathrm{x}$ & 1 detik & Menyala \\
\hline 2. & Kondisi Kosong ke 2 & $\checkmark$ & $\mathrm{x}$ & 1 detik & Menyala \\
\hline 3. & Kondisi Setengah ke 1 & $\mathrm{x}$ & $\checkmark$ & 0 & Mati \\
\hline 4. & Kondisi Setengah ke 2 & $\mathrm{x}$ & $\checkmark$ & 0 & Mati \\
\hline 5. & Kondisi Penuh ke 1 & $\mathrm{x}$ & $\checkmark$ & 0 & Mati \\
\hline 6. & Kondisi Penuh ke 2 & $x$ & $\checkmark$ & 0 & Mati \\
\hline
\end{tabular}
pakan di batas 20 gram akan membuat motor servo dalam kondisi mati dan terbuka.

Tabel 3. Pengujian Sensor waterlevel dan waterpump

Dengan hasil pungujian sensor pada tabel 3, didapatkan kondisi jika batas minimal ketinggian air dibawah $1 \mathrm{~cm}$ makan waterpump akan menyala selama 1 detik.

\section{Pengujian Browser}

Tabel 4. Tabel Pengujian Browser

\begin{tabular}{|c|l|c|c|c|}
\hline No & Fungsi Yang Diuji & $\begin{array}{c}\text { Mozilla } \\
\text { Firfox }\end{array}$ & $\begin{array}{c}\text { Microsoft } \\
\text { Edge }\end{array}$ & $\begin{array}{c}\text { Google } \\
\text { Chrome }\end{array}$ \\
\hline 1 & Login & $\checkmark$ & $\checkmark$ & $\checkmark$ \\
\hline 2 & Halaman Dasboard & $\checkmark$ & $\checkmark$ & $\checkmark$ \\
\hline 3 & Halaman Nilai Sensor & $\checkmark$ & $\checkmark$ & $\checkmark$ \\
\hline & Suhu & $\checkmark$ & $\checkmark$ & $\checkmark$ \\
\hline & Kelembaban & $\checkmark$ & $\checkmark$ & $\checkmark$ \\
\hline & Status Pakan & $\checkmark$ & $\checkmark$ & $\checkmark$ \\
\hline & Status Minum & $\checkmark$ & $\checkmark$ & $\checkmark$ \\
\hline & Tabel Datatables & $\checkmark$ & $\checkmark$ & $\checkmark$ \\
\hline 4 & Sensor & & & \\
\hline
\end{tabular}

Keterangan:

$\checkmark$ : Berhasil

$\mathrm{X}$ : Gagal

\section{KESIMPULAN DAN SARAN}

\subsection{Kesimpulan}

Hasil pengujian keseluruhan alat dapat berjalan dengan baik dan dapat berjalan sesuai dengan fungsi yang diharapkan.

1. Dari hasil perhitungan, diketahui pengujian alat menggunakan sensor dht11 memiliki nilai keakuratan sebesar $\pm 93.82 \%$ dengan rata presentase error sebesar $6,28 \%$, sensor load cell memiliki nilai rata presentase error sebesar $3,08 \%$ sedangkan tingkat error pada sensor waterlevel sebesar $0,18 \%$.

2. Didapatkan tingkat keberhasilan sistem pada penelitian memiliki nilai akurasi yang didapatkan dari perbandingan output dengan matlab. Rata-rata akurasi yang didapatkan yaitu 98.30\%

3. Nilai yang didapatkan dari sensor yang digunakan dapat berjalan baik dan dapat ditampilkan secara realtime. 


\subsection{Saran}

Berdasarkan kesimpulan yang telah peneliti berikan didapatkan saran untuk pengembangan sistem selanjutnya antara lain:

1. Menggunakan beberapa sensor dengan sensitifitas lebik baik agar hasil yang didapatkan akan lebih akurat.

2. Menambahkan fitur lain untuk mendapatkan informasi dari sistem monitoring dengan tepat seperti notifikasi via email.

3. Mengimplementasikan metode fuzzy lainnya untuk mendapatkan tingkat hasil ouput yang lebih baik.

\section{DAFTAR PUSTAKA}

[1] Yolnasdi, Arviansyah, Dedy Irfan dan Ambiyar, "RANCANG BANGUN PENGONTROL SUHU RUANGAN BERBASIS MIKROKONTROLLER ARDUINO UNO," Journal of Information Technology and Computer Science (INTECOMS), pp. 218-226, 2020.

[2] A. A. Fathkhur Rohman, Julian Sahertian dan Ardi Sanjaya, "IMPLEMENTASI FUZZY LOGIC MAMDANI UNTUK PENGENDALIAN SUHU DAN KELEMBABAN PADA TERRARIUM REPTIL DAN MONITORING BERBASIS IOT," Seminar Nasional Inovasi Teknologi, pp. 43-48, 2020.

[3] Abi Tresna, "Implementasi Logika Fuzzy pada Sistem Monitoring Online Suhu Sapi Potong berbasis IOT," Jurnal Mahasiswa Teknik Informatika, pp. 16-24, 2021.

[4] Eka Pratama Saksono, "Rancang Bangun Kontrol Suhu Dan Kelembaban Pada Kumbung Jamur Berbasis Logika Fuzzy Menggunakan Metode Telemetri," Jurnal Teknik Elektro, pp. 375-381, 2019.

[5] Allya Allan Putra Syah, Ketty Siti Salamah dan Eko Ihsanto, "Sistem Pemberi Pakan Otomatis, $\mathrm{Ph}$ Regulator dan Kendali Suhu Menggunakan Fuzzy Logic Pada Aquarium," Jurnal Teknologi Elektro, Universitas Mercu Buana, pp. 194-201, 2019.

[6] N. Febriany, "Universitas Pendidikan Indonesia," Aplikasi Metode Fuzzy Mamdani Dalam Penentuan Status Gizi Dan Kebutuhan Kalori, pp. 28-29, 2016.

[7] Pippa Elliot, "Cara Menjaga Agar Hamster Tetap Dingin dalam Cuaca Panas," [Online]. Available: https://id.wikihow.com/MenjagaAgar-Hamster-Tetap-Dingin-dalam-CuacaPanas/.

[8] Tetyana Kovyrina, "Cara Merawat Hamster Bagi Pemula Agar Sehat dan Berkembang Biak," $2102020 . \quad$ [Online]. Available: https://www.rumah.com/panduanproperti/hamster-37051.

[9] Petronela Putri, "Fakta Unik Hamster, Si Mungil yang Menggemaskan," 942017. [Online]. Available: https://bobo.grid.id/read/08674250/fakta-unikhamster-si-mungil-yang-menggemaskan.

[10] Escadio, "Mengenal board Uno R3," [Online]. Available: https://ecadio.com/mengenal-danbelajar-uno-r3.

[11] Agus faudin, "Tutorial Arduino mengakses module RTC DS3231,” 312 2017. [Online]. Available: https://www.nyebarilmu.com/tutorial-arduinomengakses-module-rtc-ds3231/.

[12] Agus Faudin, “Apa itu modul ESP8266 berserta penjelasannya," 227 2017. [Online]. Available: https://www.nyebarilmu.com/apa-itu-modulesp8266/.

[13] Lab Elektronika, "CARA PROGRAM LCD KARAKTER 16x2 MENGGUNAKAN ARDUINO DAN SIMULASI PROTEUS," 263 2017. [Online]. Available: http://www.labelektronika.com/2017/03/caraprogram-lcd-karakter-16x2-Arduno-danProteus.html.

[14] Agus Faudin, "Tutorial Arduino mengakses driver motor L298N," 279 2017. [Online]. Available:

https://www.nyebarilmu.com/tutorial-arduinomengakses-driver-motor-1298n/.

[15] "Gusmi Tasari," 254 2021. [Online]. Available: https://www.gamelab.id/news/468-mengenavisual-studio-code.

[16] M. R. Adani, 264 2021. [Online]. Available: https://www.sekawanmedia.co.id/apa-ituxampp/.

[17] I. Syafitri, 305 2019. [Online]. Available: https://www.nesabamedia.com/pengertianlocalhost/.

[18] M. Robith, 159 2020. [Online]. Available: https://www.sekawanmedia.co.id/pengertianmysql/.

[19] Padma, 151 2021. [Online]. Available: https://www.dinginaja.com/2021/01/fritzingsoftware-gambar-elektronika.html.

[20] “UnisaYogya," 1410 2020. [Online]. Available: https://psti.unisayogya.ac.id/2020/10/14/apa-ituframework-codeigniter/.

[21] Putra, 411 2019. [Online]. Available: https://salamadian.com/pengertian-webbrowser/.

[22] Wibawanto, Desain dan Pemrograman Multimedia Pembelajaran Interaktif, Jember: Cerdas Ulet Creatif, 2017. 